\title{
Berichtigung zu der Arbeit „Die Antigenstruktur des B. typhi und ihre Bedeutung für die Herstellung von Typhusimpistoffen.“6
}

$$
\text { Von }
$$

\section{A. Giovanardi}

in Heft 3, S. 273.

$$
\begin{aligned}
& \text { Seite } 282 \text { Tabelle } 3 \text { Spalte } 5 \text { Zeile } 3 \text { lies } 43 \text { anstatt } 13^{1}
\end{aligned}
$$

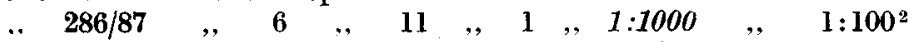

$$
\begin{aligned}
& \begin{array}{llllllllllll}
\text {," } & 286 / 87 & \text {, } & 6 & , & 11 & , & 3 & , & 1: 500 \quad, & \text { fehlt }
\end{array}
\end{aligned}
$$

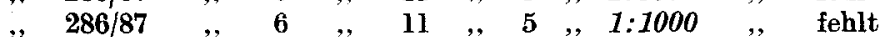

$$
\begin{aligned}
& \text { " } 286 / 87 \quad, \quad 6 \quad, \quad 12,, \quad 1 \quad, \quad 1: 5000 \quad, \quad 1: 1: 5000 \\
& \text {, } 286 / 87 \quad, 6 \quad 6 \quad, \quad 12 \quad, \quad 2 \quad, \quad 1: 2500 \quad, \quad 1: 2: 500
\end{aligned}
$$

Seite 294 Zusammenfassung PunktI, Zeile 7, lies inagglutinabel anstatt agglutinabel.

1 Zahl der überlebenden Mäuse.

¿ Bactericides Vermögen des Serums gegenüber Stamm V. 